\author{
Case Study \\ www.ijrap.net (ISSN:2229-3566)
}

\title{
MANAGEMENT OF DIABETIC PERIPHERAL NEUROPATHY WITH SPECIAL REFERENCE TO PRAMEHA UPADRAVA: A CASE STUDY
}

Seetha Devi ${ }^{1 *}$, Anisha M. S ${ }^{2}$

${ }^{1}$ Reader and Head, Department of Panchakarma, JSS Ayurveda Medical College, Mysore, Karnataka, India

${ }^{2}$ PG Scholar, Department of Panchakarma, JSS Ayurveda Medical College, Mysore, India

Received on: 21/05/20 Accepted on: 11/07/20

\author{
*Corresponding author \\ E-mail: drsitadevi@gmail.com
}

DOI: $10.7897 / 2277-4343.110482$

\begin{abstract}
Diabetic Peripheral Neuropathy (DPN) is one of the most common micro vascular complications of Diabetes Mellitus. It is characterized by paraesthesia, significant deficits in tactile sensitivity, vibration sense, lower limb proprioception and Kinaesthesia. In Ayurveda the symptoms pertaining to Diabetic Peripheral Neuropathy is explained in the Poorva Roopa and Upadrava of Prameha. A 66 Year old male patient, consulted OPD of JSS Ayurveda College and Hospital presented with the complaints of Daha in Ubhaya Pada associated with Suptata and Chimachimayana since 2 years, aggravated since 1 month .He was a K/C/O DM since 20 years and was under medication for the same. He was diagnosed with Diabetic Neuropathy. Examination revealed, the muscle sensory system examination, Light touch, Superficial sensation, Deep sensation were Present, Temperature was normal, Joint position sense was intact, Two-point discrimination was intact, Point localization was intact, Stereognosis was intact, Touch and pressure sensation screening was intact, Test for vibration loss-patient could feel the vibration on distal Hallux joint, Test for temperature sensation-patient could differentiate cold and hot. The condition was treated considering it as Madhumeha Upadrava; the condition was managed with Sarvanga Udvartana, Sarvanga Abhyanga, Ardhamatrika Basti, Takra Dhara and Shamana Aushadhi. Remarkable improvement was seen in the symptoms and blood sugar level too.
\end{abstract}

Keywords: Diabetes Mellitus, Diabetic Peripheral Neuropathy, Panchakarma, Shamana Aushadhi.

\section{INTRODUCTION}

Diabetes mellitus is a heterogeneous metabolic disorder characterized by common features of chronic hyperglycemia with disturbance of carbohydrate, fat and protein metabolism due to absolute or relative deficiency in insulin secretion and/or action or both ${ }^{1}$. Uncontrolled diabetes mellitus leads to acute complications and uncontrolled diabetes over a prolonged period of time leads to chronic complications. Diabetic neuropathy is one among the chronic complication of diabetic neuropathy ${ }^{2}$. Diabetic neuropathy is defined as signs and symptoms of nerve dysfunction in a patient with Diabetes Mellitus (DM) in whom other causes of nerve dysfunction have been excluded. The prevalence of Diabetic Peripheral Neuropathy is generally estimated to be $10-30 \%$ in patients with Diabetes Mellitus. Prevalence of neuropathy in diabetic patients ranges from around $10.5 \%$ to $32.2 \%$ in various studies across India ${ }^{3}$.

Diabetic peripheral neuropathy may be due to sensory and/ or motor and may involve small or large fibres, or both ${ }^{4}$. Large fibre involvement causes painless paraesthesia with impairment of vibration, joint position, touch and pressure sensations and loss of ankle reflex. Small fibre neuropathy on the other hand is associated with pain, burning and paraesthesia ${ }^{5}$.

Symptoms of Diabetic Peripheral Neuropathy are scattered in the Poorva Rupa (prodromal symptoms) and Upadrava (complications), but may be correlated to Upadravas it manifests secondary to Diabetes Mellitus. The Prakupita Vata with other Doshas and Dhatukshyaja Avastha results in the manifestation of Upadravas $^{6}$ and exhibit the symptoms such as Makshikopasarpanam, Suptata due to Kapha Dosha, Daha and
Paridhupana are attributed to Pitta Dosha, Kampa, Shoola ${ }^{7}$ and Dourbalya $^{8}$ are caused due to Vata.

A case reported in our hospital was diagnosed with Diabetic Neuropathy and was treated for the same considering as Prameha janya Upadrava.

\section{Case report}

A 66 Year old male patient moderately built belonged to upper middle class society, businessman by profession from Mysore, consulted OPD of JSS Ayurveda College and Hospital on 4.1.2020. Patient was a K/C/O DM since 20 years and under medication for same presented with the complaints of Daha in Ubhaya Pada associated with Suptata and Chimachimayana since 2 years, aggravated since 1 month. Daha and Chimachimayana were gradual in onset, present throughout the day with no association of pain and with no specific aggravating or relieving factors. Suptata aggravates during night.

Personal history revealed vegetarian diet, micturition 5-6 times during day and 2-3 times at night, regular bowel and disturbed sleep. Examination revealed HMF was intact, Muscle tone normal, Muscle power - 5/5, Sensory system examination Light touch, Superficial sensation, Deep sensation were Present, Temperature was normal, Joint position sense was intact, Twopoint discrimination was intact, Point localization was intact, Stereognosis was intact, Touch and pressure sensation screening was intact, Test for vibration loss-patient could feel the vibration on distal Hallux joint, Test for temperature sensation- Patient could differentiate cold and hot. 


\section{Investigation}

FBS and PPBS on 4.1.2020

FBS- $204 \mathrm{mg} / \mathrm{dl}(70-100 \mathrm{mg} / \mathrm{dl})$

PPBS $-272 \mathrm{mg} / \mathrm{dl}(110-150 \mathrm{mg} / \mathrm{dl})$
Based on Clinical features it was diagnosed as Diabetic peripheral neuropathy and considering it as Prameha Upadrava the following treatment plan is made.

\section{Treatment adopted}

Table 1: The treatment plan

\begin{tabular}{|c|c|}
\hline Treatment & Duration \\
\hline Sarvanga Udvartana with Kolakulathadi Churna. & \\
& 4 days alternatively. \\
Sarvanga Abhyanga with Dhanvantara Taila and Nadi Sweda. & 8 days \\
\hline Takradhara & 8 days \\
\hline Yoga Basti-Ardhamatrika Basti &
\end{tabular}

Table 2: Contents of Ardhamatrika Basti

\begin{tabular}{|c|c|c|}
\hline Treatment & Dose & Duration \\
\hline Anuvasana Basti & & 5 Days \\
\hline Ashwagandha Bala Lakshadi Taila & $80 \mathrm{ml}$ & \\
\hline Niruha Basti & & 3 days \\
\hline Ashwagandha Bala Lakshadi & $80 \mathrm{ml}$ & \\
\hline Madhu & $100 \mathrm{ml}$ & \\
\hline Saindhava Lavana & 10 grams & \\
\hline Shatpushpa Kalka & 15 grams & \\
\hline Madanphala & 1 & \\
\hline Dashmoola Kashya & $300 \mathrm{ml}$ & \\
\hline
\end{tabular}

Table 3: The schedule of Ardhamatrika Basti

\begin{tabular}{|c|c|c|c|c|c|c|c|}
\hline Day-1 & Day- 2 & Day- 3 & Day -4 & Day-5 & Day- 6 & Day-7 & Day-8 \\
\hline A & N & A & N & A & N & A & A \\
\hline
\end{tabular}

Table 4: Shamana Aushadhis

\begin{tabular}{|c|c|c|c|}
\hline Shamana aushadhi & Dose & Anupana & Duration \\
\hline Cap Nishamalaki & $2-0-2(\mathrm{a} / \mathrm{f})$ & Ushnajala & 15 days \\
\hline Ashwagandha Choorna & 5 grams-0-5 grams (a/f) & Go Ksheera & 15 days \\
\hline
\end{tabular}

\section{Ethical consideration}

The study is carried out as per Declaration of Helsinki guidelines.

\section{General consent}

The general consent from the patient was obtained before starting the treatment.

\section{RESULT}

After Udvartana and Abhyanga, Chimachimayana reduced on $5^{\text {th }}$ day.

There was reduction in Daha after Ardhamatrika Basti on $8^{\text {th }}$ day. After Shamana Aushadhi there was an improvement in the symptoms and blood sugar level.

\section{Investigation}

FBS and PPBS on 11.2.2020

PPBS - $169 \mathrm{mg} / \mathrm{dl}$

FBS- $123 \mathrm{mg} / \mathrm{dl}$

\section{DISCUSSION}

The explanation of symptoms of diabetic neuropathy are scattered in the Purvarupa and Upadrava of Prameha. Diabetic Neuropathy can be correlated to Prameha Upadravas as generally patient approaches the physician in the Vyakta Avastha of the Vyadhi or when Upadravas have already been manifested. In this case
Vyatyasa Chikitsa is carried out in the form of Udvartana and Abhyanga, on alternate days. Udvartana is done to remove Kapha Avarana. Abhyanga is done with Dhanvantara Taila which is Vata Kaphahara. Takradhara is a type of the Shirodhara procedure it improves the circulation of blood, which in turn reduces peripheral resistance. Ardhamatrika Basti is Vata Pittahara, it reduces Daha.

Capsule Nishamalaki refers to group of combination of Haridra and Amalaki. Amalaki is Tridoshahara, Prameha Nashaka and Rasayana. Nisha is Kapha Pittahara and Prameha Nashaka. Nishamalaki possess anti hyperglycemic, Anti diabetic, insulin mimetic, $\alpha$-Amylase inhibitory and $\alpha$ - glucosidase inhibitory, antioxidant properties. It improves insulin sensitivity, increases glucose uptake by skeletal muscles.

Ashwagandha Choorna is Kapha Vata Shamaka, Balya and Rasayana. It helps in increasing insulin secretion and improves insulin sensitivity in muscle cells. Ashwagandha possesses neuroprotective and immunomodulating properties.

\section{CONCLUSION}

Diabetes Mellitus related complications are preventable with good glycemic control. Combined effect of Udvartana, Abhyanga, Shirodhara, Ardhamatrika Basti and Shamana Aushadhi helps in the reduction of symptoms caused due to diabetic peripheral neuropathy and maintaining the glycemic control. 


\section{ACKNOWLEDGEMENT}

Author acknowledges the patient for the patient's co-operation during the treatment period.

\section{REFERENCES}

1. Aspi F. Golwalla and Sharukh A Golwallaeditors, Golwalla's Medicine, $23^{\text {rd }}$ edition, New Delhi, Jaypee Brothers Medical Publishers; Chapter 6, sub chapter 7; 2011. p. 383.

2. In: Munjal YP and Manish Modieditors. API Textbook of Medicine; $9^{\text {th }}$ edition, Vol 1; Mumbai, The Association of Physicians of India, Diabetic Neuropathy; 2012. p. 382.

3. Trivedi S, Pandit A, Ganguly G, Das SK et al. Epidemiology of Peripheral Neuropathy: An Indian Perspective, Annals of Indian Academy of Neurology 2017; Jul-Sept 20(3): 173-184.

4. In: Munjal YP and Manish Modi editors. API Textbook of Medicine; $9^{\text {th }}$ edition, Vol 1; Mumbai, The Association of Physicians of India, Diabetic Neuropathy; 2012. p. 383.

5. In: Munjal YP and Manish Modi editors. API Textbook of Medicine; $9^{\text {th }}$ edition, Vol 1; Mumbai, The Association of Physicians of India, Diabetic Neuropathy; 2012. p. 384.
6. Sushruta: Sushruta Samhita with Nibandha Sangraha and Nyayachandrika commentary of Dalhana, Edited by Vaidya Yadavji Trikamji Acharya and Narayana Ram Acharya; Published by Chaukhambha Surbharati Prakashan, Varanasi; Edition, Nidana Sthana, Chapter 6, Shloka - 13; 2012. p. 291.

7. Sushruta: Sushruta Samhita with Nibandha Sangraha and Nyayachandrika commentary of Dalhana, Edited by Vaidya Yadavji Trikamji Acharya and Narayana Ram Acharya; Published by Chaukhambha Surbharati Prakashan, Varanasi; Edition, Nidana Sthana, Chapter 7, Shloka - 13; 2012. p. 292.

8. Agnivesha, Charaka Samhita with Ayurveda Dipika commentary of Chakrapani, edited by Vaidya Yadavji Trikamji Acharya, Varanasi: Chaukhambha Prakashan, Reprint 2013; Nidana sthana Chapter 4, Shloka - 47; p. 215.

\section{Cite this article as:}

Seetha Devi P and Anisha M. S. Management of Diabetic Peripheral Neuropathy with special reference to Prameha Upadrava: A Case Study. Int. J. Res. Ayurveda Pharm. 2020;11(4):25-27 http://dx.doi.org/10.7897/2277-4343.110482

\section{Source of support: Nil, Conflict of interest: None Declared}

Disclaimer: IJRAP is solely owned by Moksha Publishing House - A non-profit publishing house, dedicated to publishing quality research, while every effort has been taken to verify the accuracy of the content published in our Journal. IJRAP cannot accept any responsibility or liability for the site content and articles published. The views expressed in articles by our contributing authors are not necessarily those of IJRAP editor or editorial board members. 